\title{
Lengua
}

\section{Посланието на патриарх Фотий до българския княз Борис-Михаил и неговият славянски превод}

\author{
Татяна СлАвовА \\ Софийски университет „Св. Климент Охридски” \\ tatyana_slavova@abv.bg
}

Recibido: Mayo de 2014

Aceptado: Diciembre de 2014

\begin{abstract}
Резюме
Статията разглежда славянския превод на Посланието на патриарх Фотий до българския княз БорисМихаил, запазен само в руски преписи от началото на XVI до началото на XX в. Специално внимание се отделя на езика на славянския превод (правопис, морфосинтаксис, лексика и словообразуване), чрез който става възможно датирането на превода, тъй като липсват всякакви други (литературни, исторически, палеографски, кодикологични) сведения за това. Изследването на езика позволява преводът да се отнесе към книжовната продукция на XIV в. и по-точно към школата на Евтимий Търновски. Причината за появата на славянския превод на Фотиевия трактат трябва да се търси в основното послание на съчинението - запазване устоите на християнската вяра и въплъщаването й в държавното управление.
\end{abstract}

Ключови думи: патриарх Фотий, княз Борис-Михаил, лингвистичен анализ, патриарх Евтимий Търновски.

La Epistola del Patriarca Focio al príncipe Boris-Miguel de Bulgaria y su traducción eslava

\section{Resumen}

El artículo estudia la traducción eslava de la Epístola del patriarca Focio al príncipe búlgaro Boris-Miguel, conservada únicamente en copias rusas desde principios del s. XVI hasta principios del s. XX. Se presta una atención especial a la lengua de la traducción eslava (ortografía, morfosintaxis, léxico y formación de palabras) que posibilita la datación de la traducción, ya que faltan cualquier tipo de indicios de otra índole (literarios, históricos, paleográficos o codicológicos). La investigación de la lengua permite atribuir la traducción a la producción literaria del s. XIV y más concretamente a la escuela literaria del Patriarca Eutimio de Tărnovo. La razón que propiciaría la traducción eslava de la Epístola de Focio la tenemos que buscar en el mensaje principal de la obra: conservar los fundamentos de la fe cristiana y materializarla en el gobierno estatal.

Palabras clave: Patriarca Focio, príncipe Boris-Miguel, análisis lingüístico, Patriarca Eutimio de Tărnovo.

The Slavonic Translation of Patriarch Photios'Letter to the Bulgarian Prince Boris-Michael

\begin{abstract}
The article explores the Slavonic translation of Patriarch Photios' letter to the Bulgarian prince BorisMichael, which has been preserved only in Russian copies from the beginning of the 16th century until the beginning of the 20th century. Special attention is paid to the language of the Slavonic translation - its orthography, morphology and syntax, vocabulary and word formation. It is precisely on the basis of the language that the translation can be dated as there are no literary, historical, paleographical codicological and other evidence about it. The investigation of the language allows for the translation to be traced back to the literary production of the 14th century, more precisely, to the school of Euthymius of Turnovo. The reason behind the creation of the Slavonic translation of Photios' treatise should be sought in its primary message - to sustain the foundations of the Christian faith and its embodiment in the running of the state.
\end{abstract}

Key words: Patriarch Photios, prince Boris-Michael, linguistic analysis, Patriarch Euthymius of Turnovo. 
Непосредствено след Покръстването на българите патриарх Фотий пише Послание до българския княз Борис-Михаил ${ }^{1}$ - своеобразно църковно-религиозно и политическо наставление в две части: първата - догматическо изложение на православието (със Символа на вярата и разказ за Седемте вселенски събора), а втората - практическо политико-дидактическо напътствие за поведението на княза. Грьцкият текст е издаван неколкократно - най-рано през 1651 г. от епископ Монтакуций (Монтакуциус, Монтегю) от Ордена на йезуитите (MONTACUTIUM 1651: 1-45), а впоследствие от Баснагий (BASNAGE 1725), Булгарис (BULGARIS 1775), Мин в Patrologia graeca (MIGNE 1864: 628-696) и Валетта (ВА^ЕTTA 1864: № 6). Осемдесет години по-късно Лаурдас и Вестеринк (LAURDAS, WESTERINK 1983: 1-39) изготвят критическо издание по седем гръцки ръкописа - един от IX в. (Baroccianus gr. 217), един от X в. (Ambrosianus B4sup.), един от XIII в. (Parisinus gr. 1266), три от XIV в. (Atheniensis Bibl. Nat. 2756, Parisinus gr. 1335, Vaticanus gr. 2195) и един от XVI в. (Athous Iberoroum 684). Документиран е интересът към трактата на Фотий и през XIX в. - грьцкият му текст е преписан (1852 г.) от българския йеромонах Дамаскин Велешки (Дамаскин Рилец). През 1917 г. митрополит Симеон (СИМЕОН, МИТР. 1917) публикува гръцкия текст и бележките на Валетта в превод на български. Съществува също съкратен превод на френски (BERNARD THÉATIN 1718)2 , на английски (WHITE 1981: 115-185; WHITE,

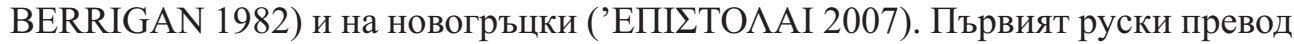
на Посланието е от 1779 г., осъществен от Юста Драницын и съхранен в руски ръкопис от XVIII в.

Върху трактата на патриарх Фотий е натрупана богата литература, която свидетелства за трайния интерес към него в цяла Европа (по-нова библиография у KEIPERT 1988: 90-94; PODSKALSKY 2000: 53-54; НИКОЛОВ 2006: 47-53; ТЪПКОВА-3АИМОВА 2008: 19-20). Коментирано е с оглед на: съдържанието, структурата, жанровите особености, целта и предназначението, източниците на Фотиевите политико-етически възгледи, цариградския Фотиев модел на идеалния християнизиран владетел, византийската доктрина за изкуството да се управлява, византийския принцип за сьгласието между светската и църковната власт и други аспекти. В изследователската традиция се разглежда и като своеобразен справочник за обучение по история и догматика на Църквата, а сьщо и като вид “княжеско огледало”.

Славянският превод на Фотиевото послание до българския княз БорисМихаил не е особено популярен, още по-малко изследван. Запазен е в над 15 руски преписа от XVI-XIX в. (в пълна и съкратена версия). Пьлната версия е засвидетелствана в 8 преписа - 7 са от началото до 60-те години XVI в. (Руска държавна библиотека - РГБ, ф. 178, № 3112, л. 635а-693б; Държавен исторически музей - ГИМ, Син № 384/235, л. 283-329; РГБ, ф. 113, № 522, л. 380б-

\footnotetext{
${ }^{1}$ Точната дата на Посланието остава неизвестна, но в изследователската традиция то се датира между 864 средата на 866 г. (СИМЕОН, МИТР. 1917: 27; ЗЛАТАРСКИ 1927: 71-72; LAURDAS, WESTERINK 1983: 1; PODSKALSKY 2000: 53; НИКОЛОВ 2006: 47; БОЖИЛОВ 2008: 131; ОБОЛЕНСКИ 1971 [2001: 117]; ГЮЗЕЛЕВ 2006: 30, 48).

2 Монах Бернар от ордена на театинците адресира текста до малолетния крал Людовик XV, на когото е бил наставник.
} 
456; РГБ, ф. 113, № 488, л. 1а-51а; РГБ, ф. 113, № 489, л. 363б-397б; РГБ, ф. 113, № 506, л. 257a-291а; ГИМ, Син № 996, л. 932-948), а един е от XVII в. (РГБ, ф. 310, № 588, л. 1а-82б) ${ }^{3}$. Съкратената версия ми е позната по 4 руски преписа от XVI, XVII и XVII-XVIII в. (РГБ, ф. 113, № 522, л. 466a-472; Руска национална библиотека - РНБ, сб. на Санкт-Петербургската духовна академия № 52, л. 306а-311б; РГБ, ф. 209, № 572, л. 318б-321; ГИМ, сб. на Хлудов № 333, л. 3286-331a; ГИМ, сб. на Вахрамеев, л. 41-43). Преводът на ськратената версия съвпада с превода на пълната версия, което означава, че тя е вторична. Оцелелият брой на славянските преписи говори за сравнително широко разпространение на съчинението. Текстологичното му проучване показва една затворена традиция със сравнително малко различия между отделните ръкописи (СЛАВОВА 2013: 122-141). Извън ръкописната традиция славянският превод е известен и от състава на печатната Кирилова книга (1644 г.), глава 47.

Посланието на патриарх Фотий до българския княз Борис-Михаил се споменава в писмо от 1489 г. на новгородския архиепископ Генадий до архиепископа на Ростов Йоасаф по повод нарастващото разпространение на еретически учения в Новгород. Това е свидетелство, че през втората половина (най-късно третата четвърт) на XV в. славянският превод на трактата вече е битувал в Русия. Въпреки че е познат само по руски преписи и че се вписва за дълго време (от края на $\mathrm{XV}$ до началото на $\mathrm{XX}$ в.) в руското църковно и книжовно пространство, където получава истинска реализация и разпространение, смятам, че преводът не е възникнал в Русия, а в България, както свидетелстват редица българизми в текста на всички руски преписи. На мястото на $\boldsymbol{x}$ и жк очаквано стоят руските рефлекси юу/ю, но ж често се открива в някои ръкописи. Обичайно \& се пази на етимологичното си място след затвърдели палатали, предава се с ґ след палатали и някои вокали и с а след затвърдели шушкави съгласни. Понякога обаче в един и същи препис (дори на един и същи лист)

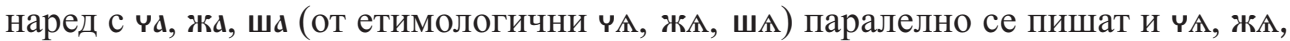
шА. Подобно колебание вероятно е последица от разминаването между руското произношение (респ. правопис) и българска подложка, от която може да са попаднали формите с $\AA$ и ж. Праславянските сонори се предават с руските рефлекси є $\rho, \boldsymbol{\rho}, \boldsymbol{⿰ ㇒}$ отделни преписи рефлексите Праславянските сьчетания * $t j$, * $d j$ очаквано са с рефлекси ч, ж, но в някои преписи има и жА. Редица от изброените правописни особености (вж. и други у СЛАВОВА 2013: 20-28) се срещат и в руските рькописи от XV-XVI в. в резултат на т. нар. “второ южнославянско влияние”. Под това понятие най-често се разбира проникването в Русия на оригинални и преводни южнославянски съчинения, които под въздействие на среднобългарската норма внасят изменения в правописа, надредните знаци, пунктуацията, почерците, украсата и оформлението на ръкописите. Ето защо правописните особености в текста на Фотиевото послание не винаги могат да се отдадат на среднобългарска подложка и сами по себе си не могат да бъдат надежден аргумент за български

3 Повечето преписи са публикувани (СИНИЦЫНА 1965; СЛАВОВА 2013: 161-245). 
произход на превода. Българска книжовна норма обаче подсказват някои фонетични и структурни граматически явления като кратките форми на личното местомение (тл, нн, мы), наличието на дателен притежателен и дуални форми, последователно прокараната втора палатализация, спорадичните форми без епентетично $л$, формите с епентеза на А в съчетанието зя, дателните форми на личното местоимение само във вида тєь', сєьћ, генитивното окончание при сложните прилагателни и причастия -аго, изобилието от форми за прост и първи сигматичен аорист, окончанието -тъ за сег. вр. 3 л. ед. ч. наред с окончание -ть. Отделни архаични редки лексеми и гърцизми, не дотам ясни на руски-

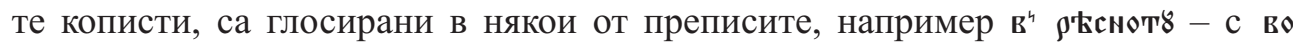

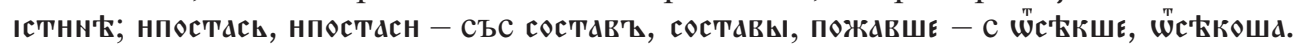
Тези лингвистични характеристики насочват към предполагаем български архетип на славянския превод на Фотиевото послание до княз Борис-Михаил.

Един от най-важните въпроси, свързани с архетипа на този превод, е този за времето на неговото възникване. Някои от съществуващите предположения (предимно екстралингвистични) отнасят възникването на славянския превод на Фотиевото послание в България към края на IX-началото на X в. (ГЮЗЕЛЕВ 1969: 317; ГЮЗЕЛЕВ 1985: 21; БОЖИЛОВ, ГЮЗЕЛЕВ 1999 [2006: 194]). Тъй като в отделни ръкописи от XVI в. (РГБ, ф. 113, № 522; РГБ, ф. 113, № 489; РГБ, ф. 113 № 506) преводът на Посланието се помества заедно със славянските преводи на Изложението на Агапит и Поучителните глави на император Василий I към сина му Лъв, други изследователи допускат появата на този цикъл от сродни по тематика поучителни съчинения да е свързана с книжовна дейност в България около началото на X в., “но тази хипотеза не може да се счита за окончателно доказана" (НИКОЛОВ 2006: 219). Според Златарски преводът на трактата до княз Борис-Михаил е извършен на славянския юг в края на XIV-началото на XV в. (ЗЛАТАРСКИ 1917: 8) - впоследствие мнението му е възприето от СИМЕОНОВА 1988: 100; PODSKALSKY 2000: 54; БОЖИЛОВ 2008: 131. Предположението на Златарски се основава на многото българизми в текста и на преписването му заедно със Словата на Григорий Цамблак. “Обаче въпросът, де именно и от кого е бил направен тоя превод, си остава засега открит и без никакъв отговор по липса на каквито и да било данни изобщо, затова и всякакви предположения и догадки по него ще бъдат не само излишни, но и неуместни” (ЗЛАТАРСКИ 1917: 8). Шестдесет години по-късно въпросът къде се е появил първоначално преводът на Фотиевото послание “сред българска или сръбска културна общественост" - продължава да е неустановен (КУЕВ 1980: 125). Поради факта, че в една група ръкописи (ГИМ, Син № 384/235; РГБ, ф. 113 № 488) Фотиевото послание е в обкръжението на съчинения на Максим Грек, други изследователи приписват превода на този руски книжовник (ХАРИТОНОВА 2008) или предполагат, че ако преводът не е негово дело, той поне е редактирал съществуващ вече превод (СИНИЦЫНА 1965: 98; БУЛАНИН 1984: 98). За Кайперт (KEIPERT 1988) преводачът на Фотиевото послание е сред представителите на филологическата традиция в Новгород от края на XV - средата на XVI в. Основанието на учения е силното присъствие в славянския текст на Фотий на категорията одушевеност при 
сыществителните имена, респективно голямата фреквентност на генитивните плурални окончания -ов $\mathbf{z} /$-єн, които се откриват и в руския превод на класическата латинска граматика на Донат, осъществен през първата половина на XVI в. в Новгород от Дмитрий Герасимов. Това граматическо явление обаче не е характерно само за живия руски език от XV-XVI в., тъй като е прието за норма в множество южнославянски ръкописи още през XIV в. В същото време Кайперт отбелязва високата степен на познаване и владеене на гръцкия език от страна на преводача и признава, че това е необичайно за шестнадесетото столетие в Русия.

При липсата на преки исторически и литературни свидетелства единствено проучването на езика би могло да хвърли светлина по въпроса кога и къде е извършен преводът. Този факт наложи езиково проучване на морфосинтакстичните, лексикалните и словообразувателните особености на славянския текст, което насочва към тезата, че първоначалният превод е извършен на славянския юг през XIV в. от представител на Търновската книжовна школа (по-подробно СЛАВОВА 2013: 43-121). Връзката с нея в областта на именната система е явна по отношение на задължителната мъжколична родително-винителна форма (включително и след предлози), нормирането на определени окончания при съществителните в резултат на взаимното влияние между склонитбените типове, изразяването на степен при прилагателните, слабото присъствие на кратките дателни притежателни форми на личното местоимение, употребата само на удължени форми при някои показателни местоимения (тюн, сєн, сї̈, тнн, тї̈, сї̈, та^), функционирането на показателното местоимение түь (рядко сь) като третолично в косвените падежи, използването на показателни местоимения с определителна служба при пълна липса на определителен член, окончателното изместване на акузативната анафорична форма н от генитивната єго, превръщането на относителното местоимение в средство за изразяване на определеност чрез калкиране на предпоставения грьцки определителен член, употребата на

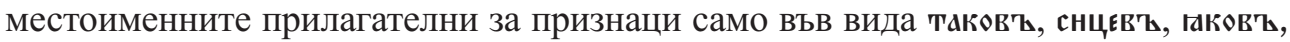
каковъ. Преводачът на Фотиевото послание следва книжовната практика на Патриарх Евтимий и неговите последователи и по отношение на глаголната система, в която инфинитивът е непокътнат (без замяна с да-конструкция и съкращаване) и няма супин. При императива и презенса е съхранено старобългарското състояние, петте спрежения са добре запазени, без следи от прегрупиране, а при тематичните глаголи липсва новото окончание за 1 л. мн. ч. -ны. Простото бъдеще време е основен начин за изразяване на футурни действия и почти не се използват граматикализирани описателни форми. Няма форми за прост (с изключение на 3 л. ед. ч.) и първи сигматичен аорист със запазена сигма, а преобладаващо се употребяват форми за първи и втори сигматичен аорист. Не се откриват и имперфектни форми от сегашната глаголна основа. Разрастването на вторичната имперфективация е добре изразена тенденция, като предпочитан словообразувателен модел е този на -ьствоватн, формиран предимно от адективна и субстантивна основа. Не се наблюдават случаи, в които причастието и определеният глагол се свързват чрез съюза н, което би разколебало същинското причастно значение и би отдалечило езика от старобългарската книжовна норма. 
Свидетелства за връзка на славянския текст на Фотиевото послание с търновската книжнина представят и определени синтактични характеристики изобилието на синтактични и причастни конструкции, разграничаването на посесивните употреби на родителен и дателен падеж, избягването на генитив след глаголи с отрицание, липсата на общи форми след предлози, превръщането на съчетанието въ + име в генитив + нксто в предлога въытсто, следван от име в генитив. Постигането на формално тъждество с гръцкия образец личи особено при словореда, към който преводачът се пръдържа стриктно, понякога дори в нарушение на славянската реч, например когато предлогът остава разделен от думата или отрицателната частица мє е на дистанция от съответния глагол. Рядък случай на променен гръцки словоред е постпозицията на задлога

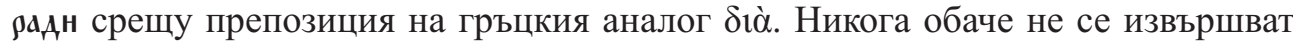
съществени словоредни изменения въпреки някои несвойствени за славянския словоред черти, като например поставяне на сказуемото или подлога в края на изречението, разкъсване на определението и определяемото с интерполиране между тях на други части на речта, изнасяне в начало на изречението на част от допълнението, което завършва чак в края на изречението и др.

Лексикалните и словообразувателните особености на славянския превод на Посланието на патриарх Фотий също го обвързват с българската писмена традиция от четиринадесетото столетие и с представителите на Търновската школа (СЛАВОВА 2013: 103-121, речник-индекс на словоформите на с. 246325). Близостта е в богатата лексикална синонимия, използването на речниковия фонд на двете основни средища Охрид и Преслав, но с превес на кирилометодиевизмите, употребата на общосрещани и общодостъпни думи и ограничаването на специфичните речникови единици, сьвпадането при редките лексеми най-често с превода на Исай Серски на Ареопагитиките (1371 г.), съчиненията на Григорий Цамблак, среднобългарския (XIV в.) превод на 16-те слова на Григорий Богослов, съчиненията на Патриарх Евтимий. В славянския превод на Фотиевото послание са отразени и голяма част от предпочитаните в Евтимиевата школа словообразувателни модели, като тези на -кнє при Nomina actionis et resultativa, на -нє и -ость при абстрактните съществителни, на -тєль и

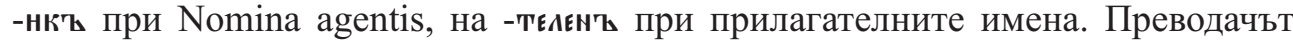
следва типичната за тази школа тенденция да се употребяват лексеми с префикси и суфикси за сметка на думите с проста морфемна структура, воден и от жанровите и стилистичните особености на Посланието.

С традициите на търновските книжовници кореспондира и преводаческият подход към оригинала на патриарх Фотий - постигане на максимална близост с него на всички езикови равнища. Основен принцип за преводача е стриктното придържане към първоизточника, чиято текстова цялост е добре запазена. Пропуските и добавките, фигуриращи във всички славянски преписи, са минимални. Проява на стремежа към структурно тъждество с гръцкия първообраз е тенденцията към точно възпроизвеждане на гръцките сложни думи (75\% от всичките композита са пълни структурни калки), пословният превод, избягването на двойното отрицание и на двойственото число, преводът на гръцките отрицателни форми с $\alpha$-privativum чрез лексе- 
ми с представки нє- и вє马- и само по изключение описателно с предлог вєз и съществително.

Затова преводът на Фотиевото послание до княз Борис-Михаил не би могъл да се датира преди края на XIV в. Голяма част от морфосинтактичните, лексикалните и словообразувателните характеристики на славянския текст имат аналог в книжовната норма, възприета от атонските редактори и преводачи в началото на XIV в., впоследствие кодифицирана в Търново от Патриарх Евтимий. Всички тези параметри, взети в тяхната съвкупност, не биха могли да намерят отражение в превода, ако преводачът на Посланието не е бил специално обучен да ги спазва. Затова би могло да се твърди, че той е представител на Търновската книжовна школа.

Каква е причината славянският превод да се появи 5 века след написването му от патриарх Фотий? Тя трябва да се търси в основното послание на съчинението - запазване устоите на християнската вяра и въпльщаването й в държавното управление. Съхраняването на православието и борбата с ересите е изведено като главна идея не само в първата част на Посланието, но и във втората - своеобразно ръководство за владетелско управление, изцяло подчинено на християнската идея. Подобна тематика е особено актуална за края на четиринадесетото столетие на славянския юг с оглед на историческия контекст и случващите се политически събития преди залеза на Второто българско царство. Още по времето на цар Иван Александър множество емблематични за епохата български паметници съдържат текстове, дискутиращи специално въпросите на вярата, които служат на официалната власт като опора срещу появилите се еретически брожения през XIV в. Например в Лаврентиевия сборник (1348 г.) са поместени Написание за правата вяра, Цьрковно учение за светата вяра и сведения за Седемте вселенски събора; в състава на Песнивеца (1337 г.) има тълкувание на Символа на вярата и Тълкувание на Господнята молитва; в Поп-Филиповия сборник (1345 г.) наред с Манасиевата хроника присъства и Книга за вярата. Причините, предизвикали включването на изброените катехитично-догматични творби в български (предимно царски) кодекси от XIV в., ще да са същите, довели до превода на патриаршеското послание.

Важен факт е, че поместеният в него Никео-Цариградски символ на вярата е в същата редакция, в която е засвидетелстван Символьт и в състава на три среднобългарски ръкописа от XIV в. Единият е Палаузовият препис на Бориловия синодик (Народна библиотека “Кирил и Методий”, София - НБКМ 289 /55, края на XIV в.), който във втората си част съдържа хороса на Шестия вселенски събор със съставни части Символите на вярата на Никейския събор и на Втория вселенски събор в Константинопол (БОЖИЛОВ, ТОТОМАНОВА, БИЛЯРСКИ 2010: 62, 242-243). Вторият ръкопис с Никео-Цариградския символ на вярата в своя състав е Карадимовият (Шопов) псалтир (НБКМ № 454 и № 1138, първа половина на XIV в.) ${ }^{4}$. Третият ръкопис е т. нар. Ряпов сборник със смесено съдържание (БАН № 80, края на XIV в.), в който на л. 329а е

4 Изказвам сърдечна благодарност на Елена Коцева за предоставената ми информация. 
поместен Никео-Цариградският символ на вярата като част от по-голяма ста-

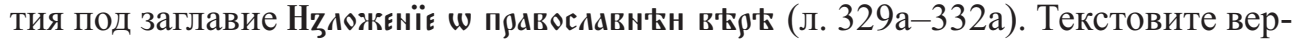
сии на Символа на вярата в Посланието на Фотий, Бориловия синодик, Карадимовия (Шопов) псалтир и Ряповия сборник напълно съвпадат, което е още един аргумент за принадлежността на славянския превод на Фотиевото послание към българска книжовна практика от четиринадесетото столетие.

Друг аргумент в тази посока са използваните от преводача новозаветни цитати, съвпадащи с атонската редакция на Евангелието и Апостола, която става основа на Евтимиевата редакция, въведена в Търново и в цялата българска църква през 70-те години на XIV в. Бихме могли да намерим още една възможна причина славянският превод на Фотиевото послание да се появи към края на XIV в., ако погледнем на него като на текст, съхранил част от историята на Първото българско царство. С такава цел по времето на цар Иван Александър се превеждат хрониките на Константин Манасий, Йоан Зонара и Симеон Логотет, където византийските автори разглеждат историята на Византия като продължение на Римската империя, а българската история като нейна съставна част. Подобна роля би могъл да изпълнява и славянският превод на Фотиевото послание до владетеля Бори-Михаил като свидетелство, че българската държава има многовековна история, която е част от историята на “семейството на християнските владетели и народи”.

В този контекст трябва да се отбележи и характерният за четиринадесетото столетие пиетет към културното и книжовното наследство на Първата българска държава и особено към владетелската институция, който обуславя стремежа да се възпроизвеждат предходни образци на владетелска книга. Не случайно съставът на един от царските сборници - Лаврентиевия от 1348 г. - показва редица паралели на текстово и на функционално равнище с Цар-Симеоновия сборник (по Светославовия препис 1073 г.). С малки изключения всички текстове в Лаврентиевия сборник представят старинни преводи - така в него съзнателно е отразена тенденцията за повторение на древните книги на българските царе, разбира се, актуализирани с адекватни на вкусовете и потребностите на времето нови творби (ВЕЛИНОВА 2012: 276-280). Архаична версия, аналогична на глаголическия Синайски псалтир, съдържа друг царски кодекс Песнивецът от 1337 г., а вмъкнатите в средата на псалтирния текст Тълкувание на Господнята молитва и Тълкувание на Символа на вярата също отпращат към образци от X в. (МИЛТЕНОВА 2005). Затова е естествено книжовниците от XIV в. да се обърнат към един текст като Посланието на патриарх Фотий, свързан с Първата българска държава.

Така макар и предназначено за българския княз Борис-Михаил, Посланието надхвърля рамките на своя адресат. Разпространението му в гръцки преписи от XIII до XVI в., в руски ръкописи от XVI до XIX в., наличието на славянска печатна версия, на църковнославянски препис (1852 г.), както и наличието на латински (1651 г.), френски (1718 г.) и руски (1779 г.) преводи показват, че то е било актуално през цялото Средновековие за православните християни във Византия и Slavia Orthodoxa, но също и за католиците в Западна Европа от времето на Просвещението. Като политическо и литературно четиво трактатьт на 
патриарх Фотий е препоръчван на цар Иван Грозни и приблизително два века по-късно е четен на малолетния крал Людовик XV. И в Русия от края на XVначалото на XVI в. са съществували исторически предпоставки за нуждата от текст като Посланието във връзка с ереста на “жидовстващите”. Езиковото проучване обаче показва, че преводът може да се датира приблизително век порано и тогава той би могъл да се обвърже, най-общо казано, и със славянския юг, и със Света гора. Най-вероятно преводачът, който владее отлично гръцки език, е работил в голям скрипториум, с достъп до владетелски документи. Където и да е бил извършен преводът на Фотиевото послание, той е осъществен от високо ерудиран представител на Евтимиевата книжовна школа, който на практика прилага нейните езикови и литературни норми. Не само езикът на превода, но и историческият контекст е в полза на хипотезата, че именно през Второто българско царство е възникнала необходимостта от подобен превод, свързан с държавността и вярата.

\section{Библиография}

БОЖИЛОВ, ИВ. (2008): Византийският свят. Le monde byzantine, Анубис, София.

БОЖИЛОВ, ИВ., В. ГЮЗЕЛЕВ (1999, 2 изд. 2006): История на средновековна България VII-XIV в., Т. 1. Анубис, София.

БОЖИЛОВ, ИВ., А. ТОТОМАНОВА, ИВ. БИЛЯРСКИ (2010): Борилов синодик. Издание и превод, ПАМ Пъблишинг Къмпани, София.

БУЛАНИН, Д. (1984): Переводы и послания Максима Грека, Наука, Ленинград.

ВЕЛИНОВА, В. (2012): “Сборниците от времето на Йоан-Александър и съдбата им в балканската книжовна традиция", в Beati Possidentes. Юбилеен сборник, посветен на 60-годишнината на проф. дфн Боряна Христова, с. 276-287, София.

ГЮЗЕЛЕВ, В. (1969): Княз Борис Първи. България през втората половина на $I X$ в., Наука и изкуство, София.

ГЮЗЕЛЕВ, В. (1985): “Цариградският Фотиев модел на християнизиран владетел - бивш езичник”, Die slawischen Sprachen, 9, с. 19-31, Salzburg.

ГЮЗЕЛЕВ, В. (2006): Покръстване и християнизачия на българите, Тангра ТанНакРа, София.

ЗЛАТАРСКИ, В. (1917): “Посланието на цариградския патриарх Фотий до българския княз Борис в славянски превод”, Български старини, 5, с. 3-64, София.

ЗЛАТАРСКИ, В. (1927): История на българската държава през средните векове. Т. 1. Първо българско ичарство. Ч. 2. От славянизацията на държавата до падането на Първото иарство, Дьржавна печатница, София.

КУЕВ, К. (1980): “Посланието на патриарх Фотий до българския княз Борис", в Руско-южнославянски книжсони връзки, София, с. 120-128.

МИЛТЕНОВА, А. (2005): “Тълкованието на молитвата “Отче наш" в Песнивеца на Иван Александър", в Acta palaeoslavica. In honorem professoeis Angelinae Minčeva, T. 2. Heron Press, Sofia, c. 83-92. 
НИКОЛОВ, А. (2006): Политическа мисъл в ранносредновековна България (средата на IX-края на Х век), Парадигма, София.

ОБОЛЕНСКИ, Д. (1971 [2001]): Византийската общност. Източна Европа 500-1453, Университетско издателство “Св. Климент Охридски”, София. [The Byzantine Commonwealth, Eastern Europe, 500-1453, London, 1971].

СИМЕОН, митрополит, (1917): "Посланието на цариградския патриарх Фотия до българския княз Бориса. Преведе от гръцки митрополит Симеон", Български старини, 5, с. 3-138.

СИМЕОНОВА, Л. (1988): "Византийската концепция за изкуството да се управлява според Фотиевото послание до княз Борис I", Проблеми на кулmурата, № 4, с. 91-104.

СИНИЦЫНА, Н. В. (1965): "Послание константинопольского патриарха Фотия князю Михаилу Болгарскому в списках XVI в.”, Труды отдела древнерусской литертуры, 21, с. 96-125, Москва.

СЛАВОВА, Т. (2013): Славянският превод на Посланието на патриарх Фотий до княз Борис-Михаил, Университетско издателство “Св. Климент Охридски", София.

ТЪПКОВА-ЗАИМОВА, В. (2008): “Трима папи и двама патриарси в църковната политика на Борис I (през погледа на някои български историци)”, в Християнска култура в средновековна България. Материали от начионална научна конференция, Шумен 2-4 май 2007 г. по случай 1100 години от смъртта на св. княз Борис-Михаил (ок. 835-907 г.), Фабер, В. Търново, с. $13-22$.

ХАРИТОНОВА, М. А. (2008): "Послание патриарха Фотия болгарскому князю Борису-Михаилу в переводе Максима Грека: характерные языковые черты и переводческие приемы", в Материаль международной научно-богословской конференции "Россия - Афон: тысячелетие духовного единства", Москва, с. $328-333$.

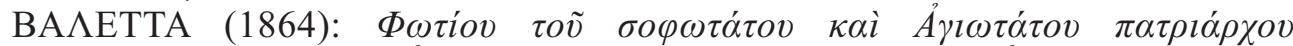

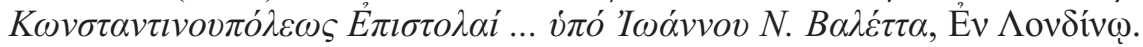

BASNAGE, J. (1725): "De Photio epusque scriptis observation", Thesaurus monumentorum ecclesiasticorum et historicorum, T. 2. Amstelodami, 382-419.

BERNARD THÉATIN (1718): Maximes pour la conduite du prince Michel, roi de Bulgarie, traduites du Grec en vers Français et présentlées au Roi par D. le père Bernard Théatin, Paris.

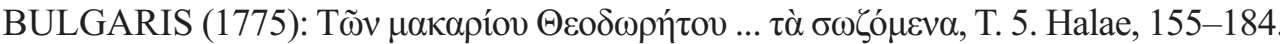

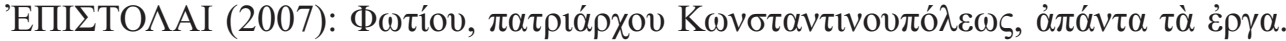

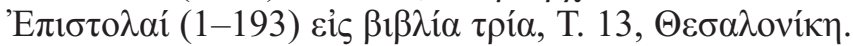

KEIPERT, H. (1988): "Die slavische Übersetzung des Photius-Briefs an BorisMichael von Bulgarien", Gattungen in den slavischen Literaturen. Beiträge zu ihren Formen in der Geschichte, Festschrift für A. Rammelmeyer, Böhlau, 89113.

LAOURDAS, B., L. G. WESTERINK (1983): Photii Patriarchae Constantinopolitani Epistulae et Amphilochia, Ed. B. Laourdas et L. G. Westerink, Vol 1, Lipsae. 
MIGNE, J. P. (1864): Patrologia Graeca. Photii Opera. T. 102. Parisiis, col. 627-696.

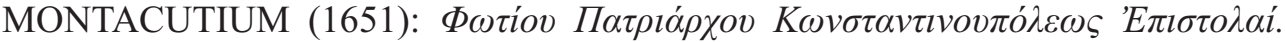
Photii Sanctissime Patriarchae Constantinopolitani Epistolae, per ... $R$. Montacutiu, Londoni.

PODSKALSKY, G. (2000): Theologische Literatur des Mittelalters in Bulgarien und Serbien 865-1459, München.

WHITE, D. S. (1981): Patriarch Photios of Constantinople. His life, scholary contributions and correspondence together translation of fifty-two of his letters, Brookline.

WHITE, D. S., J. R. BERRIGAN (1982): The Patriarch and the Prince. The Letter of Patriarch Photios of Constantinople to Khan Boris of Bulgaria, Brooklin. 